\title{
Boron doped nanocrystalline silicon film characterization for solar cell application
}

\author{
Chao Song ${ }^{1,2^{*}}$, Xiang Wang ${ }^{1}$, Jie Song ${ }^{1}$, Zhenxu Lin ${ }^{1}$, Yi Zhang ${ }^{1}$, Yanqing Guo ${ }^{1}$ and Rui Huang ${ }^{1}$
}

\begin{abstract}
Lightly doped hydrogenated amorphous silicon thin films were deposited through the plasma enhanced chemical vapor deposition (PECVD) technique using a gas mixture of $\mathrm{SiH}_{4}, \mathrm{~B}_{2} \mathrm{H}_{6}$, and $\mathrm{H}_{2}$ as the precursor. By using thermal annealing at 800 and $1000^{\circ} \mathrm{C}$, boron doped nanocrystalline silicon films were obtained. X-ray photoelectron spectroscopy (XPS) measurements demonstrated the presence of substitutional boron in the doped films. Based on the measurement of dark conductivity as a function of temperature, p-type nanocrystalline silicon (nc$\mathrm{Si}: \mathrm{H})$ films with high room temperature conductivity and low active energy were observed. By using these p-type silicon films, $\mathrm{P}-\mathrm{N}$ junction solar cells were prepared on the n-type nc-Si substrate. The device characteristics were investigated based on the measurements of the current-voltage and spectral-response.
\end{abstract}

\section{INTRODUCTION}

Due to their applications in optoelectronic devices, amorphous silicon (a-Si:H) thin films have been investigated widely, and the optical and electric properties of a-Si:H thin films have been reported in many studies [1-3]. Compared with a-Si:H films, nanocrystalline silicon (nc-Si:H) films consisting of crystallites and amorphous phases exhibit many novel characteristics such as high conductivity, low activation energy, and high photo-absorption coefficient. These characteristics are due to the fact that these films can be easily doped and also due to the quantum size effect [4-6]. In order to further improve the performance of the device, a study on the microstructures and physical properties of nc-Si:H films is required to be carried out. Many efforts have been made aiming to perform fundamental studies on the microstructure and carrier transport in nc-Si:H films [7,8]. Meanwhile, for the application in devices such as thin film solar cells, the structure and performance of silicon thin films should be tailored by doping. It has been reported that the diffusion length and mobility of carriers in doped nc-Si:H films can be improved by the treatment of doping, and the band structures of the film can be adjusted by controlling the size of nanocrystals based on the quantum confinement effect $[9,10]$. The use of doped nc-Si:H films in solar cells, instead of a-Si:H films, overcomes the light induced degradation effect, which improves the power conversion efficiency of cells. As a result, it is an important issue to realize the influence of doping on carrier transport and optical properties.

In our previous work, intrinsic and doped silicon films have been prepared and investigated considering the changes from amorphous to nanocrystalline structures $[11,12]$. In this work, we report on the structural, electronic, and optical properties of p-type nc-Si:H thin films tailored for solar cells. Then, we discuss the performance of the P-N junction solar cells with p-type nc-Si:H films on n-type nc-Si substrate by using the current-voltage and spectral-response measurements.

\section{EXPERIMENTAL SECTION}

The films and P-N junctions considered in this study were fabricated using plasma-enhanced chemical vapor deposition (PECVD) system at substrate temperature of $250^{\circ} \mathrm{C}$. Boron doped hydrogenated a-Si:H films for the structural, electrical, and optical measurements were deposited on quartz plates. Silane $\left(\mathrm{SiH}_{4}\right)$, diborane $\left(\mathrm{B}_{2} \mathrm{H}_{6}, 5 \%\right.$ in $\left.\mathrm{H}_{2}\right)$, and hydrogen $\left(\mathrm{H}_{2}\right)$ were used as the source gases. During the growth process, the flow rate of $\mathrm{SiH}_{4}, \mathrm{~B}_{2} \mathrm{H}_{6}$ and $\mathrm{H}_{2}$ was maintained at $1.5,0.5$, and $80 \mathrm{sccm}$, respectively. The radio frequency $(\mathrm{RF})$ power was maintained at $30 \mathrm{~W}$. The pressure in the chamber was maintained at $60 \mathrm{~Pa}$ by controlling the pumping speed. The thickness of films was approximately $300 \mathrm{~nm}$. After the deposition, the samples were individually annealed in the conventional furnace at temperatures of 800 and $1000^{\circ} \mathrm{C}$ for $1 \mathrm{~h}$ in nitrogen ambient.

The P-N junction cells were fabricated through the following deposition sequence. First, 100 nm thick p-type a-Si:H films were deposited on n-type c-Si substrates, and

\footnotetext{
${ }^{1}$ Department of Physics and Electrical Engineering, Hanshan Normal University, Chaozhou 521041, China

${ }^{2}$ School of Electronic Science and Engineering and National Laboratory of Solid State Microstructures, Nanjing University, Nanjing 210093, China

*Corresponding author (email: songchao511@126.com)
} 
then annealed in a conventional furnace at temperatures of 800 and $1000^{\circ} \mathrm{C}$ for $1 \mathrm{~h}$ in nitrogen ambient. Then, an $\sim 200 \mathrm{~nm}$ thick transparent conducting film was sputtered in Ar plasma using a 2 wt. $\% \mathrm{Al}_{2} \mathrm{O}_{3}$ doped $\mathrm{ZnO}$ ( $\left.\mathrm{ZnO}: \mathrm{Al}\right)$ target through a shadow mask to form top electrodes with diameter of $1.5 \mathrm{~mm}$. The substrate temperature, pressure, and $\mathrm{RF}$ power during the process was $150^{\circ} \mathrm{C}, 1.0 \mathrm{~Pa}$, and $300 \mathrm{~W}$, respectively. Finally, an $\sim 300 \mathrm{~nm}$ thick Al film was prepared by a thermal evaporation technique, which was used as a back contact.

Temperature dependent conductivity measurements of the samples were performed in vacuum lower than $10^{-3} \mathrm{~Pa}$ using a Keithley $610 \mathrm{C}$ programmable electrometer. Before the measurements, all the samples were heated at $423 \mathrm{~K}$ for $30 \mathrm{~min}$ to remove the absorbance from the films. Then, the dark conductivity measurements were performed at temperatures ranging from $423 \mathrm{~K}$ to room temperature. The optical band gap of the films was deduced using the transmission spectra measured through a Shimadzu UV-3600 spectrophotometer at room temperature. Raman signals were detected by a Jobin Yvon Horiba HR800 spectrometer operating at $1800 \mathrm{~g} \mathrm{~mm}^{-1}$ grating. The excitation light source is an Ar laser with a wavelength of $488 \mathrm{~nm}$. The $I V$-parameters for the cells e.g., the conversion efficiency $\left(E_{\mathrm{ff}}\right)$, were measured using an AM 1.5 sun simulator. The Oriel IQE-200 measurement system was used for the spec- tral response characterization.

\section{RESULTS AND DISCUSSION}

Raman spectra of the samples, annealed at different temperatures, are given in Fig. 1. It can be seen that the as-deposited samples exhibit a purely amorphous structure. After annealing at $800^{\circ} \mathrm{C}$, the crystallization occurs, and the degree of the crystallinity increases as the annealing temperature increases to $1000^{\circ} \mathrm{C}$. The inset of Fig. 1 shows the measured XPS spectra of the samples. The B 1s peak around $188 \mathrm{eV}$ attributed to the $\mathrm{B}-\mathrm{B} / \mathrm{B}-\mathrm{Si}$ suggests that the boron atoms are substitutionally doped in silicon films. Meanwhile, the dopant concentration is estimated to be 1.04 at.\% for the as-deposited samples, and it is increased to 1.49 at.\% for samples annealed at $1000^{\circ} \mathrm{C}$. Combining the Raman and XPS spectra, it can be seen that the boron dopant can be effectively activated by thermal annealing and the boron-doped nc-Si:H films are obtained.

By using the Tauc plot, the optical band gap $E_{\mathrm{g}}$ can be obtained using the extrapolation of the $(a h v)^{1 / 2} v s$. the photon energy $(h v)$ curve to zero ordinate [12]. Fig. 2 shows the variation in the band gap with different annealing temperatures. It can be seen that, with the increase in the annealing temperature, the optical band gap increases to $2.07 \mathrm{eV}$ for samples annealed at $1000^{\circ} \mathrm{C}$. As shown in Fig. 1, the formation of Si nanocrystals with a small size occurred after the

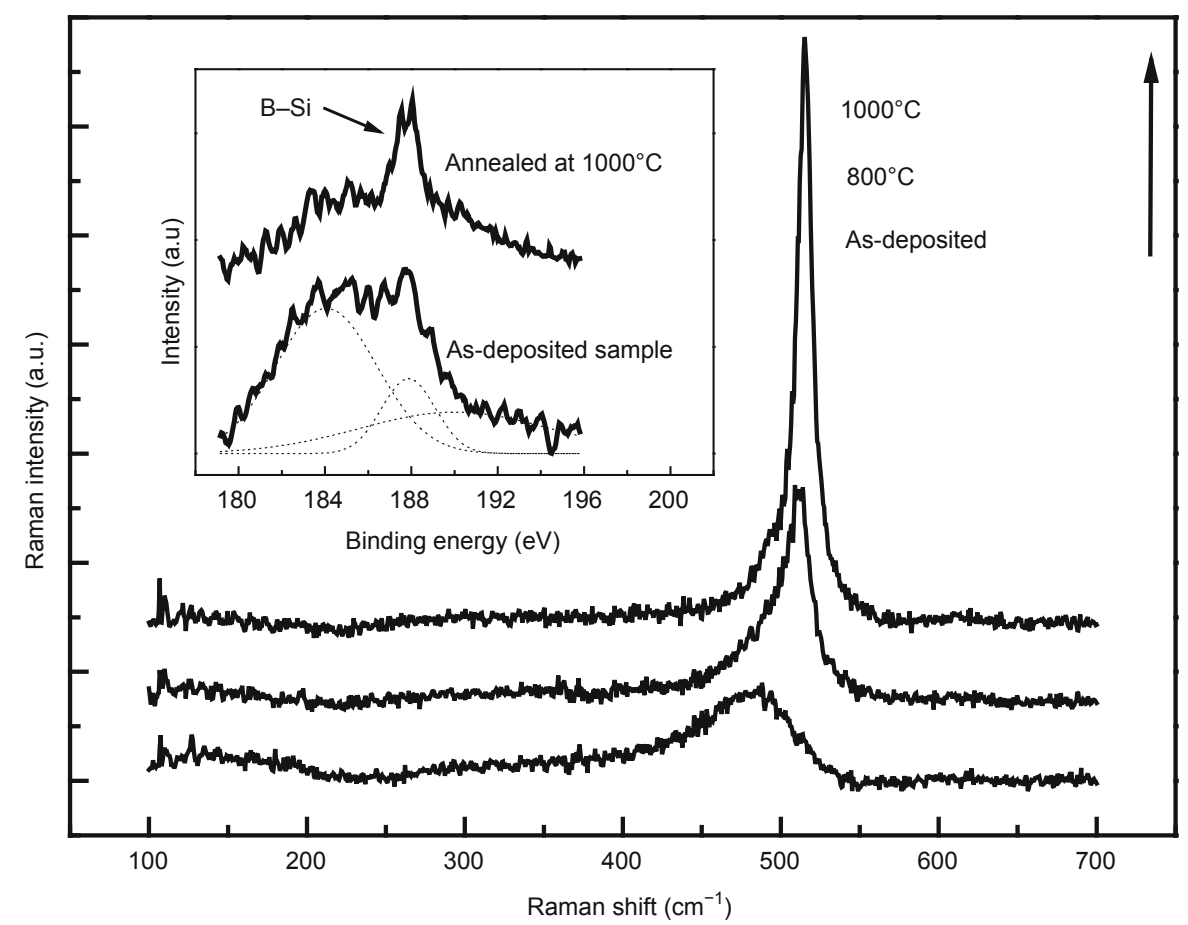

Figure 1 Raman spectra for samples annealed at different temperatures. Inset presents B 1s XPS spectrum of the as-deposited samples. 


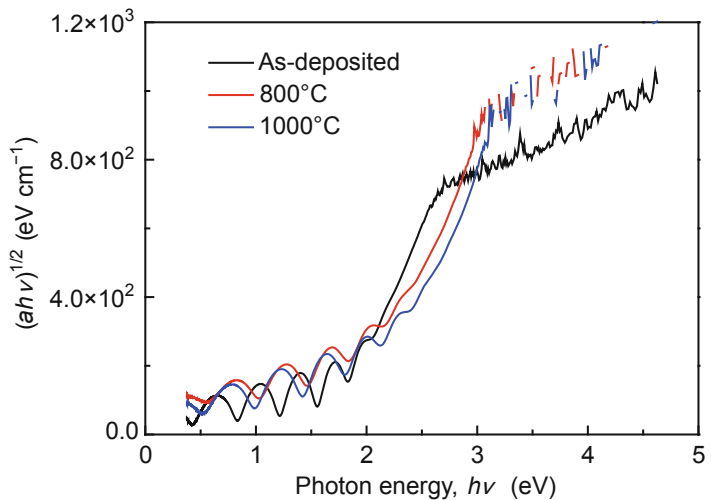

Figure 2 Variation in the optical band gap as a function of the annealing temperature.

annealing at $800^{\circ} \mathrm{C}$; this can cause an increase of the optical band gap due to the quantum confinement effect and an increase of the grain boundary. Moreover, with the increase in the volume fraction of the crystallized component, the band gap increases $[12,13]$. As a result, with the increase in the annealing temperature to 800 and $1000^{\circ} \mathrm{C}$, the degree of crystallinity is increased, and the corresponding optical band gap increases.

Dark conductivity $(\sigma)$ was measured in vacuum from room temperature to $423 \mathrm{~K}$. As shown in Fig. 3, as the annealing temperature increases to $1000^{\circ} \mathrm{C}$, the dark conductivity at room temperature approximately reaches a value of $2.0 \times 10^{2} \mathrm{~S} \mathrm{~cm}^{-1}$. From the Arrhenius plot of $\log (\sigma)$ against the reciprocal absolute temperature, the activation energy

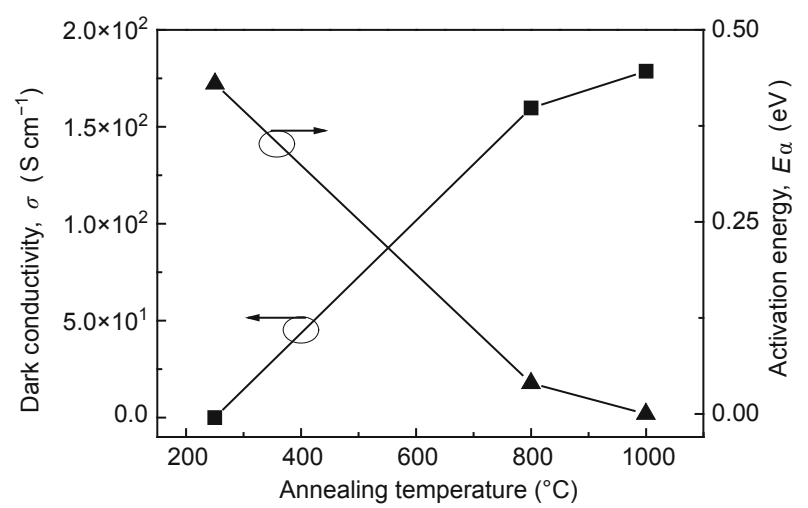

Figure 3 Values of dark conductivity and activation energy at different annealing temperatures.
$\left(E_{\mathrm{a}}\right)$ can be deduced [14]. As shown in Fig. 3, the activation energy values for the samples are below $0.5 \mathrm{eV}$. As the annealing temperature increases to $1000^{\circ} \mathrm{C}$, the activation energy rapidly decreases approximately to zero. The reduction in the activation energy for doped films indicates that a huge of doped atom in the film has been activated. This result is consistent with the results of the XPS spectra. The p-type films with low activation energy and high conductivity should be applied as the p-type layer material for solar cells [15]. Many studies have reported the changes of the optical band gap and the conductivity of silicon films by using the dopant activation and the formation of nanocrystals in films [1]. Meanwhile, it is worth pointing out that the properties of films can be affected by the surface of the films. With the increase in the annealing temperature, the surface of the films should be changed, which may affect the characteristics of the films. Further work will be performed to study the effects of silicon film surface.

For further investigation of doped silicon materials, P-N junction solar cells were prepared. By using AM 1.5 illumination, the typical current-voltage characteristics of the cells were measured. The device parameters are summarized in Table 1. It can be seen that the conversion efficiency $\left(E_{\mathrm{ff}}\right)$ is very low for the as-deposited sample. $E_{\mathrm{ff}}$ increases monotonously with the increase in the annealing temperature. The samples annealed at $1000^{\circ} \mathrm{C}$ show the best $E_{\mathrm{ff}}$ of $4.06 \%$ with high open current voltage $\left(V_{\text {oc }}\right)$, high short circuit current $\left(I_{\mathrm{sc}}\right)$, and high fill factor $(\mathrm{FF})$, which should be attributed to the formation of nc-Si:H and the activation of boron dopant as discussed in Fig. 1 [16].

Without background illumination, the external quantum efficiency (EQE) spectra were measured. As shown in Fig. 4, with the increase in the annealing temperature, the peak values of the curves are enhanced. For the sample annealed at $1000^{\circ} \mathrm{C}$, the peak values of the curves are approximately $60 \%$ in almost the entire measurement spectra range (400-1200 $\mathrm{nm}$ ). Compared with the as-deposited sample, the EQE of cells annealed at 800 and $1000^{\circ} \mathrm{C}$ is much higher, which is caused by the higher $I_{s c}$ in p-type nc-Si:H. Meanwhile, it should be noted that the conversion efficiency of the cells shown here is lower than that of the state-of-the-art silicon-based solar cells. To design a competitive device, the device structure and preparation

Table 1 Output parameters of solar cells under AM 1.5 illumination

\begin{tabular}{cccc}
\hline Annealing temperature $\left({ }^{\circ} \mathrm{C}\right)$ & $V_{\mathrm{oc}}(\mathrm{mV})$ & $I_{\mathrm{sc}}(\mathrm{mA})$ & $\mathrm{FF}(\%)$ \\
\hline As-deposited & 287 & 0.16 & 25.6 \\
800 & 367 & 0.404 & 28.4 \\
1000 & 541 & 0.455 & 2.38 \\
\hline
\end{tabular}




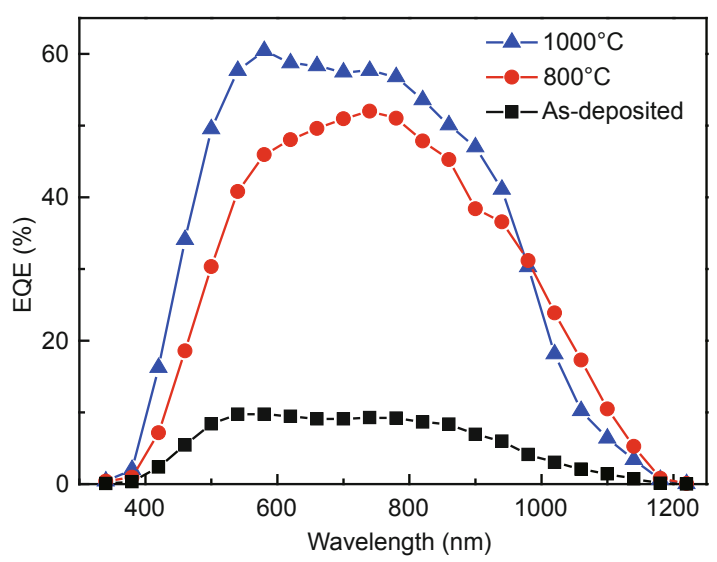

Figure $4 \mathrm{EQE}$ spectra of solar cells annealed at different temperatures.

parameter must be further optimized, by using an interface and light-trapping schemes.

\section{CONCLUSIONS}

The effect of thermal annealing on structural, optical, and electronic properties of boron-doped nanocrystalline silicon films grown by PECVD was studied. By using a post-thermal treatment, dopants can be efficiently activated in films; this leads to the formation of $\mathrm{p}$-type nanocrystalline silicon thin films with a very high value of conductivity and lower activation energy. By using the p-type silicon films, the P-N junction solar cells were fabricated and characterized on n-type nc-Si substrate. Both the external quantum efficiency and power conversion efficiency are enhanced by thermal annealing. A conversion efficiency of $4.06 \%$ was achieved for the cell annealed at $1000^{\circ} \mathrm{C}$ in the nc-Si p-layer.

Received 28 July 2015; accepted 16 September 2015; published online 22 September 2015

1 Das D, Bhattacharya K. Characterization of the Si:H network during transformation from amorphous to micro-and nanocrystalline structures. J Appl Phys, 2006, 100: 103701

2 Yoshida N, Shimizu Y, Honda T, et al. A study of absorption coefficient spectra in a-Si:H films near the transition from amorphous to crystalline phase measured by resonant photothermal bending spectroscopy. J Non Cryst Solids, 2008, 354: 2164-2166
3 Leary SK, Malik SM. A simplified joint density of states analysis of hydrogenated amorphous silicon. J Appl Phys, 2002, 92: 4276-4282

$4 \mathrm{Hu}$ GY, Connell RF, He YL, et al. Electronic conductivity of hydrogenated nanocrystalline silicon films. J Appl Phys, 1995, 78: 3945-3948

5 Yan WS, Wei DY, Guo YN, et al. Low-temperature preparation of phosphorus doped $\mu \mathrm{c}$-Si:H thin films by low-frequency inductively coupled plasma assisted chemical vapor deposition. Thin Solid Films, 2012, 520: 1724-1728

6 Saleh R, Nickel NH. Raman spectroscopy of B-doped microcrystalline silicon films. Thin Solid Films, 2003, 427: 266-269

7 Satoa K, Hirakuri K. Influence of paramagnetic defects on multicolored luminescence from nanocrystalline silicon. J Appl Phys, 2006, 100: 114303

8 Fathi E, Vygranenkob Y, Vieira M, et al. Boron-doped nanocrystalline silicon thin films for solar cells. Appl Surf Sci, 2011, 257: 8901-8905

9 Juneja S, Sudhakar S, Gope J, et al. Highly conductive boron doped micro/nanocrystalline silicon thin films deposited by VHF-PECVD for solar cell applications. J Alloy Compd, 2015, 643: 94-99

10 Cao YQ, Xu X, Li SX, et al. Improved photovoltaic properties of Si quantum dots/SiC multilayers-based heterojunction solar cells by reducing tunneling barrier thickness. Front Optoelectron, 2013, 6: 228-233

11 Song C, Xu J, Wang Q, et al. Carrier transport of doped nanocrystalline Si formed by annealing of amorphous Si films at various temperatures. Solid State Commun, 2011, 151: 697-700

12 Song C, Chen GR, Xu J, et al. Evaluation of microstructures and carrier transport behaviors during the transition process from amorphous to nanocrystalline silicon thin films. J Appl Phys, 2009, 105: 054901

13 Chen H, Gullanar MH, Shen WZ. Effects of high hydrogen dilution on the optical and electrical properties in B-doped nc-Si:H thin films. J Cryst Growth, 2004, 260: 91-101

14 Myong SY, Lim KS, Konagai M. Effect of hydrogen dilution on carrier transport in hydrogenated boron-doped nanocrystalline silicon-silicon carbide alloys. Appl Phys Lett, 2006, 88: 103120

15 Shah A, Meier J, Vallat-Sauvain E, et al. Microcrystalline silicon and 'micromorph' tandem solar cells. Thin Solid Films, 2002, 403-404: 179-187

16 Song $\mathrm{C}, \mathrm{Xu} J$, Chen $\mathrm{G}$, et al. High-conductive nanocrystalline silicon with phosphorous and boron doping. Appl Surf Sci, 2010, 257: 1337-1341

Acknowledgements This work was supported by the National Natural Science Foundation of China (61306003 and 61274140).

Author contributions Song $C$ designed the experiments and wrote the paper. Wang X, Song J, Lin Z and Zhang Y performed the experiments and characterization. Guo Y and Huang R helped with sample characterization. All the authors contributed to the general discussion.

Conflict of interest The authors declare that they have no conflict of interest. 


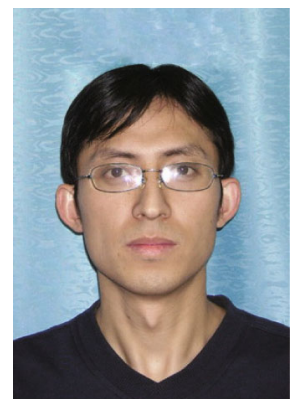

Chao Song received his PhD degree in microelectronics and solid state electronics from the Department of Physics of Nanjing University in 2010. His research interests are focused on the fabrication of silicon-based nanomaterials, and the development and understanding of doped materials for energy and light emission related applications, such as solar cells and LEDs.

中文摘要 本文采用等离子体增强化学气相沉积技术(PECVD)制备了轻度掺杂的氢化非晶硅薄膜, 沉积过程中以 $\mathrm{SiH}_{4}, \mathrm{~B}_{2} \mathrm{H}_{6}$ 和 $\mathrm{H}_{2}$ 的 混和气作为反应源. 原始淀积材料经过 800 和 $1000^{\circ} \mathrm{C}$ 的高温热退火处理后, 形成了硼掺杂的纳米硅薄膜. $\mathrm{X}$ 射线光电子能谱(XPS) 显示硼 原子在薄膜中形成了替位式掺杂. 根据不同温度下暗电导率的测量结果, 轻度硼掺杂的纳米硅薄膜具有较高的室温暗电导率和较低的 激活能. 进而, 采用该种 $\mathrm{P}$ 型硅薄膜材料以 $\mathrm{N}$ 型单晶硅为基底, 制作了 $\mathrm{P}-\mathrm{N}$ 结太阳能电池器件. 根据电流-电压特性以及光谱相应曲线的测 量分析, 对电池的性能特性进行了研究. 